Jurnal Agro 7(2), 2020

\title{
PENGARUH PEMBERIAN FOSFOR DI PEMBIBITAN TERHADAP PERTUMBUHAN DAN HASIL TANAMAN PADI PADA CEKAMAN RENDAMAN
}

\section{PHOSPHORUS APPLICATION IN SEEDLING STAGE ON GROWTH AND YIELD OF RICE UNDER SUBMERGENCE STRESS CONDITION}

\author{
Irmawati $^{1^{*}}$, Imam Wibisono ${ }^{2}$, Erise Anggraini ${ }^{2}$ \\ ${ }^{1}$ Program Studi Agronomi, Fakultas Pertanian, Universitas Sriwijaya \\ ${ }^{2}$ Program Studi Agroekoteknologi, Fakultas Pertanian, Universitas Sriwijaya \\ Jl. Palembang-Prabumulih Km.32 Indralaya, Ogan Ilir, Sumatra Selatan \\ *Korespondensi : irmawati@fp.unsri.ac.id
}

Diterima : 12 April 2020 / Disetujui: 13 Oktober 2020

\begin{abstract}
ABSTRAK
Cekaman rendaman merupakan salah satu masalah utama yang dihadapi dalam kegiatan budidaya padi di lahan rawa lebak. Tujuan penelitian ini adalah untuk mengetahui pengaruh pemberian fosfor sebelum tanaman terendam yang diharapkan mampu meningkatkan ketahanan tanaman padi terhadap cekaman rendaman. Penelitian disusun menggunakan Rancangan Petak Terbagi (Split Plot) dengan varietas padi sebagai petak utama dan waktu pemberian fosfor sebagai anak petak yang masing-masing diulang sebanyak 3 kali. Varietas padi yang digunakan yaitu IR 42, Inpari 30, dan Ciherang. Waktu pemberian fosfor terdiri dari kontrol $\left(P_{0}\right)$, pemberian fosfor 3 hari sebelum perendaman $\left(P_{1}\right), 7$ hari sebelum perendaman $\left(P_{2}\right)$, dan 14 hari sebelum perendaman $\left(P_{3}\right)$. Hasil penelitian menunjukkan bahwa Ciherang merupakan varietas yang paling terhambat pertumbuhannya akibat cekaman rendaman. Selain itu, perlakuan $\mathrm{P}_{2}$ (aplikasi fosfor pada 7 hari sebelum perendaman) menunjukkan hasil terbaik dibandingkan perlakuan lain yang secara signifikan ditunjukkan pada peubah luas daun, berat kering akar dan total berat kering tanaman pada 6 minggu setelah tanam atau 14 hari setelah perendaman. Data yang dihasilkan diharapkan mampu menjadi bahan pertimbangan dalam perbaikan teknis budidaya padi di lahan rawa lebak.
\end{abstract}

Kata kunci: Fosfor, Padi, Pemulihan, Rendaman

\begin{abstract}
One of the major constraints of rice cultivation in the non-tidal swamp area is submergence stress, which is considered could be managed by phosphorus application before submergence in order to increase rice tolerance towards submergence stress condition. Split plot design was used in this research with three replicates. Rice cultivars served as the main plot consisted of IR42, Inpari 30, and Ciherang. While for the sub-plot was phosphorus application consisted of $P_{0}$ $=$ control, $\mathrm{P}_{1}=$ phosphorus application 3 days before submergence, $\mathrm{P}_{2}=$ phosphorus application 7 days before submergence, and $P_{3}=$ phosphorus application 14 days before submergence. Results showed that Ciherang was the most affected cultivar due to submergence stress. Furthermore, $\mathrm{P}_{2}$ had better performance compared to other $\mathrm{P}$ treatments as significantly showed in leaf area, dry root weight, and total dry weight at 6 weeks after sowing or 14 days after submergence. The resulted data hopefully can be used as a consideration for swamp rice


cultivation improvement effort.

Key words: Phosphorus, Recovery, Rice, Submergence

\section{PENDAHULUAN}

Sumatra Selatan adalah provinsi dengan potensi lahan rawa yang cukup besar. Sekitar $27 \%$ dari total luas area di Sumatra Selatan adalah rawa lebak, atau sekitar 2,28 juta ha (Waluyo et al., 2006) dan hanya sekitar 285.6941 ha yang dimanfaatkan sebagai lahan sawah (BPS Sumsel, 2015). Masalah utama pada budidaya padi di lahan rawa lebak adalah resiko banjir (flash flooding) di awal musim tanam atau pada awal fase vegetatif tanaman disebabkan oleh hujan yang masih turun tidak menentu di akhir musim penghujan. Tanaman padi dapat terendam total selama beberapa hari yang akan menyebabkan gangguan pertumbuhan dan perkembangan, bahkan dapat menyebabkan kematian pada tanaman. Penelitian yang mempelajari respons tanaman padi terhadap cekaman rendaman telah banyak diteliti. Penelitian tersebut diantaranya Bhowmick et al. (2014); Huang et al. (2019); Nishiuchi et al. (2012); Setter et al. (2010); Ismail et al. (2012) menyatakan bahwa tanaman dapat mati apabila terendam total dengan durasi lebih dari satu minggu.

Penggunaan bibit dengan vigor yang baik dianggap dapat meningkatkan ketahanan tanaman terhadap cekaman rendaman. Pemberian pupuk yang mengandung Nitrogen, Fosfor dan Kalium merupakan salah satu upaya untuk meningkatkan laju pertumbuhan dan perkembangan tanaman padi pada fase vegetatif. Sayangnya, aplikasi pupuk baik jenis maupun waktu yang tidak tepat seringkali justru menjadi salah satu faktor menurunnya tingkat ketahanan bibit padi terhadap cekaman rendaman. Hasil penelitian Ella \& Ismail (2006) menunjukkan bahwa bibit padi yang diberi pupuk nitrogen sebelum perendaman memiliki persentase tingkat ketahanan yang lebih rendah, bahkan mencapai $0 \%$ pada varietas yang tidak toleran. Lebih lanjut dikemukakan bahwa aplikasi pupuk fosfor sebelum perendaman mengindikasikan hasil yang relatif lebih baik, tetapi penelitian lanjutan menunjukkan hasil yang masih belum stabil. Hasil serupa ditemukan dari penelitian Gautam et al. (2014) dimana kombinasi pemberian pupuk $P$ sebelum perendaman dan pupuk $\mathrm{N}$ setelah perendaman menunjukkan hasil terbaik terhadap ketahanan tanaman padi dalam kondisi cekaman rendaman. Meskipun demikian, informasi yang diperoleh mengenai pengaruh aplikasi pupuk $P$ sebelum perendaman dari hasil-hasil penelitian tersebut masih cukup terbatas karena aplikasi $P$ hanya digunakan sebagai salah satu kombinasi perlakuan sehingga pengaruhnya belum diketahui secara jelas terhadap pertumbuhan dan hasil tanaman padi dalam kondisi cekaman rendaman. Terkait hal tersebut, maka penelitian ini dilakukan dengan tujuan untuk mengetahui pengaruh pemberian fosfor sebelum tanaman terendam yang diharapkan mampu meningkatkan ketahanan tanaman padi terhadap cekaman rendaman.

\section{BAHAN DAN METODE}

Penelitian ini dilaksanakan pada bak penelitian Laboratorium Fisiologi Tumbuhan, Jurusan Budidaya Pertanian, Universitas Sriwijaya. Penelitian dilaksanakan pada bulan Juli sampai dengan 
November 2019. Penelitian disusun menggunakan Rancangan Petak Terbagi (Split Plot) dengan varietas padi sebagai petak utama dan waktu pemberian fosfor sebagai anak petak. Varietas padi yang digunakan yaitu IR 42 (varietas non toleran), Inpari 30 (varietas toleran), dan Ciherang (varietas padi komersial yang umum digunakan pada lahan rawa di Sumatra Selatan).

Waktu pemberian fosfor merupakan perlakuan anak petak yang terdiri dari 4 perlakuan, yaitu kontrol $\left(P_{0}\right)$, pemberian fosfor 3 hari sebelum perendaman $\left(P_{1}\right), 7$ hari sebelum perendaman $\left(P_{2}\right)$, dan 14 hari sebelum perendaman $\left(P_{3}\right)$. Setiap kombinasi perlakuan diulang sebanyak 3 kali dengan 6 tanaman untuk masing-masing unit, sehingga dihasilkan total 216 tanaman.

Adapun peubah yang diamati meliputi parameter pertumbuhan dan hasil tanaman padi, yang terdiri dari: tinggi tanaman, jumlah anakan, panjang akar, luas daun, tingkat kehijauan daun, berat kering akar, total berat kering tanaman, panjang malai dan jumlah malai per rumpun.

Benih padi disemai terlebih dahulu pada baki semai. Bibit padi kemudian dipelihara selama tiga minggu sebelum dilakukan pemindahan ke ember. Nutrisi tanaman di pembibitan dijaga dengan menambahkan secara berkala $25 \%$ konsentrasi larutan hara Kimura B pada baki semai. Perlakuan fosfor diberikan dengan cara menambahkan 30 ppm larutan fosfor ke baki semai sehingga dapat langsung diserap oleh akar bibit tanaman padi sesuai dengan masing-masing perlakuan. Pemberian $30 \mathrm{ppm}$ larutan fosfor dilakukan berdasarkan pertimbangan kisaran dosis $P$ pada larutan hara yang umumnya diberikan pada tanaman (Çalişkan \& Çalişkan, 2018). Bibit padi kemudian dipindahkan ke ember yang telah diisi dengan media tanah top soil yang sebelumnya telah dibersihkan dari serasah, dilumpurkan dan diberi pupuk dasar NPK. Ember tanaman padi kemudian direndam dalam bak penelitian $(4 \times 1,5 \times 0,8 \mathrm{~m})$ berdasarkan varietas dengan ketinggian air sekitar $50 \mathrm{~cm}$ dari dasar tanaman selama 7 hari.

Pengamatan kemudian dilakukan secara bertahap antara lain: 4 minggu setelah tanam (MST) atau tepat setelah selesai perendaman, 6 MST atau 14 hari setelah perendaman, dan pada akhir penelitian untuk mendapatkan data panjang dan jumlah malai. Pengamatan dilakukan dengan cara mengambil secara destruktif 2 sampel tanaman pada tiap unit perlakuan pada pengamatan 4 dan 6 minggu setelah tanam (MST), sementara 2 sampel tanaman lainnya terus dipelihara sampai akhir penelitian untuk mendapatkan data panjang dan jumlah malai.

Data yang dihasilkan dianalisis menggunakan analisis sidik ragam dengan membandingkan $\mathrm{F}$ hitung dengan $\mathrm{F}$ tabel. Jika $\mathrm{F}$ hitung lebih besar dari $\mathrm{F}$ tabel pada taraf $5 \%$ maka perlakuan memberikan pengaruh nyata, dan jika lebih besar dari $\mathrm{F}$ tabel pada taraf $1 \%$ maka perlakuan memberikan pengaruh sangat nyata, sementara bila $F$ hitung lebih kecil dari $F$ tabel maka perlakuan tidak berbeda nyata (Gomez et al., 1984). Uji lanjut dengan Beda Nyata Terkecil (BNT) kemudian digunakan untuk mengidentifikasi perbedaan pada tiap perlakuan.

\section{HASIL DAN PEMBAHASAN}

Analisis sidik ragam dilakukan secara terpisah pada 4 dan 6 minggu setelah tanam (MST) (Tabel 1 dan 2). Pengamatan pada 4 MST dilakukan tepat setelah tanaman selesai 
mengalami cekaman rendaman sehingga menggambarkan kondisi tanaman pada saat terendam, sedangkan pengamatan pada 6 MST menunjukkan kondisi tanaman pada 14 hari masa pemulihan setelah mengalami perendaman. Analisis sidik ragam juga dilakukan pada peubah panjang malai dan jumlah malai per rumpun yang dilakukan pada akhir penelitian yang ditunjukkan pada Tabel 3.
Hasil analisis sidik ragam menunjukkan bahwa interaksi antara varietas dengan perlakuan fosfor hanya terlihat pada peubah tingkat kehijauan daun pada 4 MST dan pada peubah berat kering akar pada 4 dan 6 MST. Uji BNT kemudian dilakukan untuk melihat perbedaan pengaruh interaksi pada ketiga peubah ini (Tabel 4).

Tabel 1. Analisis sidik ragam pengaruh pemberian fosfor pada fase pembibitan terhadap pertumbuhan tanaman padi pada kondisi cekaman rendaman pada 4 MST

\begin{tabular}{|c|c|c|c|c|c|c|}
\hline & \multirow{2}{*}{ Peubah yang diamati } & \multicolumn{3}{|c|}{ F hitung pada 4 MST } & \multicolumn{2}{|c|}{ Koefisien Keragaman (KK) } \\
\hline & & Varietas (V) & Fosfor (P) & $V \times P$ & KKa (\%) & KKb (\%) \\
\hline 1. & Tinggi tanaman $(\mathrm{cm})$ & $31,22 * *$ & $1,97^{\mathrm{tn}}$ & $2,35^{\mathrm{tn}}$ & 10,9 & 6,0 \\
\hline 2. & Panjang akar (cm) & $16,03 *$ & $1,93^{\mathrm{tn}}$ & $1,20^{\text {tn }}$ & 9,5 & 11,4 \\
\hline 3. & Luas daun $\left(\mathrm{cm}^{2}\right)$ & $66,71^{* *}$ & $2,35^{\mathrm{tn}}$ & $1,55^{\mathrm{tn}}$ & 10,6 & 20,0 \\
\hline 4. & Tingkat kehijauan daun & $145,12 * *$ & $1,01^{\mathrm{tn}}$ & $3,85^{*}$ & 11,7 & 9,7 \\
\hline 5. & Berat kering tanaman (g) & $3,34^{\text {tn }}$ & $1,38^{\mathrm{tn}}$ & $1,34^{\mathrm{tn}}$ & 37,6 & 30,8 \\
\hline 6 & Berat kering akar (g) & $9,24 *$ & $1,70^{\mathrm{tn}}$ & $4,84 * *$ & 14,6 & 16,9 \\
\hline 7. & Jumlah anakan & - & - & - & & \\
\hline & $\mathrm{F}$ tabel 0,05 & 6,94 & 3,16 & 2,66 & & \\
\hline & F tabel 0,01 & 18,00 & 5,09 & 4,01 & & \\
\hline
\end{tabular}

Keterangan: ${ }^{*}=$ nyata; $^{* *}=$ sangat nyata; $\mathrm{tn}=$ tidak nyata

Tabel 2. Analisis sidik ragam pengaruh pemberian fosfor pada fase pembibitan terhadap pertumbuhan tanaman padi pada kondisi cekaman rendaman pada 6 MST

\begin{tabular}{|c|c|c|c|c|c|}
\hline \multirow{2}{*}{ Peubah yang diamati } & \multicolumn{3}{|c|}{ F hitung pada 6 MST } & \multicolumn{2}{|c|}{ Koefisien Keragaman (KK) } \\
\hline & Varietas (V) & Fosfor (P) & $\mathrm{V} \times \mathrm{P}$ & KКа (\%) & KKb (\%) \\
\hline 1. Tinggi tanaman $(\mathrm{cm})$ & $10,23 *$ & $2,61^{\mathrm{tn}}$ & $0,61^{\mathrm{tn}}$ & 8,8 & 9,0 \\
\hline 2. Panjang akar (cm) & $8,48^{*}$ & $0,40^{\mathrm{tn}}$ & $0,41^{\mathrm{tn}}$ & 13,2 & 13,7 \\
\hline 3. Luas daun $\left(\mathrm{cm}^{2}\right)$ & $53,61 * *$ & $6,12 * *$ & $2,60^{\operatorname{tn}}$ & 14,9 & 14,7 \\
\hline 4. Tingkat kehijauan daun & $11,71 *$ & $1,03^{\mathrm{tn}}$ & $1,87^{\mathrm{tn}}$ & 4,7 & 3,3 \\
\hline 5. Berat kering tanaman (g) & $415,98 * *$ & $4,50 *$ & $2,19^{\mathrm{tn}}$ & 5,0 & 16,8 \\
\hline 6 Berat kering akar (g) & $103,14 * *$ & $7,45 * *$ & $2,68^{*}$ & 11,3 & 20,6 \\
\hline 7. Jumlah anakan & $26,80 * *$ & $3,09^{\text {tn }}$ & $1,68^{\text {tn }}$ & 12,3 & 18,6 \\
\hline $\mathrm{F}$ tabel 0,05 & 6,94 & 3,16 & 2,66 & & \\
\hline F tabel 0,01 & 18,00 & 5,09 & 4,01 & & \\
\hline
\end{tabular}

Keterangan: ${ }^{*}=$ nyata; $^{* *}=$ sangat nyata tn $=$ tidak nyata

Tabel 3. Analisis sidik ragam pengaruh pemberian fosfor pada fase pembibitan terhadap panjang malai dan jumlah malai per rumpun

\begin{tabular}{lccccc}
\hline \multirow{2}{*}{ Peubah yang diamati } & \multicolumn{3}{c}{ F hitung pada 6 MST } & \multicolumn{2}{c}{ Koefisien Keragaman (KK) } \\
\cline { 2 - 6 } & Varietas (V) & Fosfor (P) & V x P & KKa (\%) & KKb (\%) \\
\hline 1. Panjang malai $(\mathrm{cm})$ & $11,24^{*}$ & $0,06^{\text {tn }}$ & $0,49^{\text {tn }}$ & 3,0 & 3,6 \\
2. Jumlah malai per rumpun & $7,52^{*}$ & $0,98^{\text {tn }}$ & $1,93^{\text {tn }}$ & 18,3 & 7,8 \\
\hline F tabel 0,05 & 6,94 & 3,16 & 2,66 & & \\
F tabel 0,01 & 18,00 & 5,09 & 4,01 & & \\
\hline
\end{tabular}

Keterangan: ${ }^{*}=$ nyata $^{* *}=$ sangat nyata; $\mathrm{tn}=$ tidak nyata 
Pengaruh tunggal varietas sebagai petak utama memiliki pengaruh yang lebih dominan dibanding dengan pengaruh tunggal fosfor. Hal ini dapat dilihat pada hampir semua peubah kecuali pada peubah berat kering tanaman pada 4 MST. Tabel 5 menunjukkan uji BNT untuk pengaruh tunggal varietas terhadap peubah yang diamati. Varietas Ciherang menunjukkan hasil yang paling rendah pada hampir semua peubah yang diamati. Ciherang memiliki rerata tinggi tanaman dan panjang akar yang lebih panjang selama masa perendaman dibanding varietas IR 42 dan Inpari 30. Hal ini menunjukkan bahwa varietas Ciherang melakukan pemanjangan batang dan juga akar sebagai upaya keluar dari kondisi cekaman rendaman.

Tabel 4. Pengaruh interaksi perlakuan terhadap peubah tingkat kehijauan daun pada 4 MST dan berat kering akar pada 4 dan 6 MST

\begin{tabular}{|c|c|c|c|c|c|c|c|c|c|}
\hline \multirow{2}{*}{ Varietas } & \multicolumn{8}{|c|}{ Perlakuan Fosfor } & \\
\hline & \multicolumn{2}{|c|}{ P0 } & \multicolumn{2}{|c|}{ P1 } & \multicolumn{2}{|c|}{ P2 } & \multicolumn{2}{|c|}{ P3 } & \\
\hline \multicolumn{10}{|l|}{ 1. Tingkat kehijauan daun $4 \mathrm{MST}$} \\
\hline IR42 & 24,57 & $\mathrm{aC}$ & 24,47 & $\mathrm{aC}$ & 22,52 & $\mathrm{aB}$ & 23,67 & $\mathrm{aC}$ & BNT 5\% \\
\hline Ciherang & 11,15 & $\mathrm{bA}$ & 6,90 & $\mathrm{aA}$ & 11,87 & bA & 9,75 & bA & $=2,85$ \\
\hline Inpari 30 & 15,88 & $\mathrm{aB}$ & 18,50 & $a b B$ & 19,35 & $b B$ & 17,23 & $a b B$ & \\
\hline \multicolumn{10}{|c|}{ BNT $5 \%=3,32$} \\
\hline 2. Berat kering akar $4 \mathrm{MST}(\mathrm{g})$ & & & & & & & & & \\
\hline IR42 & 0,036 & $\mathrm{aA}$ & 0,042 & $\mathrm{aA}$ & 0,041 & $\mathrm{aA}$ & 0,044 & $\mathrm{aA}$ & BNT $1 \%$ \\
\hline Ciherang & 0,032 & $\mathrm{aA}$ & 0,039 & $\mathrm{aA}$ & 0,039 & $\mathrm{aA}$ & 0,043 & $\mathrm{aA}$ & $=0,015$ \\
\hline Inpari 30 & 0,041 & $\mathrm{bA}$ & 0,041 & $\mathrm{bA}$ & 0,024 & $\mathrm{aB}$ & 0,021 & $\mathrm{aB}$ & \\
\hline \multicolumn{10}{|c|}{ BNT $1 \%=0,016$} \\
\hline \multicolumn{10}{|l|}{ 3. Berat kering akar $6 \mathrm{MST}(\mathrm{g})$} \\
\hline IR42 & 0,110 & $\mathrm{aA}$ & 0,171 & bB & 0,172 & bB & 0,203 & bB & BNT 5\% \\
\hline Ciherang & 0,086 & $\mathrm{aA}$ & 0,072 & $\mathrm{aA}$ & 0,099 & $\mathrm{aA}$ & 0,079 & $\mathrm{aA}$ & $=0,048$ \\
\hline Inpari 30 & 0,119 & $\mathrm{aA}$ & 0,136 & $a b B$ & 0,211 & $b B$ & 0,177 & $\mathrm{bB}$ & \\
\hline
\end{tabular}

Keterangan: angka-angka yang diikuti dengan huruf kecil yang sama pada baris yang sama serta huruf kapital yang sama pada kolom yang sama menunjukkan perbedaan tidak nyata

Hasil analisis sidik ragam menunjukkan bahwa perlakuan fosfor memberikan pengaruh yang tidak nyata terhadap semua peubah pada tanaman dalam kondisi cekaman rendaman. Hal ini disebabkan menurunnya laju pertumbuhan semua tanaman pada cekaman rendaman. Pada 6 MST atau setelah masa pemulihan 14 hari, perlakuan fosfor memberikan pengaruh yang nyata terhadap karakter penting pertumbuhan padi yaitu pada peubah luas daun dan total berat kering tanaman.

Pada pengamatan terhadap peubah panjang malai dan jumlah malai per rumpun, hasil analisis sidik ragam menunjukkan bahwa kedua peubah ini lebih dipengaruhi oleh perbedaan varietas, sedangkan perlakuan fosfor memberikan pengaruh yang tidak nyata.

Hasil penelitian menunjukkan bahwa perlakuan fosfor tidak memberikan pengaruh nyata terhadap tinggi tanaman padi. Berdasarkan hasil pada Tabel 5, varietas Ciherang menunjukkan penambahan tinggi tanaman yang lebih besar dibandingkan 2 varietas lainnya selama 7 hari masa perendaman. Hal ini juga dapat dilihat dengan lebih jelas pada 
Gambar 1. Setelah perendaman berakhir (4 MST), Ciherang menunjukkan kecenderungan mengalami penurunan tinggi tanaman bila dibandingkan dengan IR 42 dan Inpari 30 dengan tinggi tanaman yang relatif stabil selama 7 hari masa pemulihan.
Setelah mengalami 14 hari masa pemulihan, tinggi tanaman pada ketiga varietas mulai mengalami peningkatan kembali, kecuali perlakuan $\mathrm{P}_{0}$ (kontrol) dan $\mathrm{P}_{1}$ (pemberian fosfor 3 hari sebelum perendaman) pada varietas Ciherang.

Tabel 5. Pengaruh tunggal perlakuan varietas terhadap peubah yang diamati

\begin{tabular}{|c|c|c|c|c|c|c|}
\hline & \multirow{2}{*}{ Peubah yang diamati } & \multicolumn{3}{|c|}{ Varietas } & \multicolumn{2}{|c|}{ BNT } \\
\hline & & IR 42 & Ciherang & Inpari 30 & $5 \%$ & $1 \%$ \\
\hline \multicolumn{7}{|c|}{$4 \mathrm{MST}$} \\
\hline 1. & Tinggi tanaman $(\mathrm{cm})$ & 29,72 a & $41,99 \mathrm{~b}$ & 34,39 a & - & 7,21 \\
\hline 2. & Panjang akar (cm) & $14,21 b$ & $13,37 b$ & 11,43 a & 1,40 & - \\
\hline 3. & Luas daun $\left(\mathrm{cm}^{2}\right)$ & $8,43 \mathrm{~b}$ & 5,16 a & 6,32 a & - & 1,32 \\
\hline 4. & Tingkat kehijauan daun & $23,80 \mathrm{c}$ & 9,92 a & $17,74 b$ & - & 3,76 \\
\hline 5. & Berat kering akar $(\mathrm{g})$ & $0,041 \mathrm{~b}$ & $0,038 b$ & 0,031 a & 0,006 & - \\
\hline \multicolumn{7}{|c|}{$6 \mathrm{MST}$} \\
\hline 1. & Tinggi tanaman (cm) & 39,99 a & 38,62 a & $44,95 b$ & 4,09 & - \\
\hline 2. & Panjang akar (cm) & $15,35 \mathrm{~b}$ & 12,37 a & $13,37 a b$ & 2,05 & - \\
\hline 3. & Luas daun $\left(\mathrm{cm}^{2}\right)$ & $89,13 b$ & 55,39 a & $107,36 \mathrm{~b}$ & - & 23,44 \\
\hline 4. & Tingkat kehijauan daun & $40,38 b$ & 36,81 a & $38,64 a b$ & 2,05 & - \\
\hline 5. & Berat kering tanaman (g) & $0,73 \mathrm{~b}$ & 0,41 a & $0,73 \mathrm{~b}$ & - & 0,06 \\
\hline 6. & Berat kering akar (g) & $0,164 b$ & $0,084 a$ & $0,161 b$ & - & 0,029 \\
\hline 7. & Jumlah anakan & $4,25 \mathrm{~b}$ & $3,04 a$ & $4,29 \mathrm{~b}$ & - & 0,89 \\
\hline \multicolumn{7}{|c|}{ Komponen hasil } \\
\hline 1. & Panjang malai $(\mathrm{cm})$ & 20,00 a & $21,05 b$ & $21,03 b$ & 0,71 & - \\
\hline 2. & Jumlah malai per rumpun & $16,46 \mathrm{~b}$ & 12,71 a & 13,17 a & 2,93 & - \\
\hline
\end{tabular}

Keterangan: angka-angka yang diikuti dengan huruf yang sama pada baris yang sama menunjukkan perbedaan tidak nyata

Tinggi tanaman merupakan salah satu karakter pertumbuhan yang dianggap dapat mengindikasikan tingkat ketahanan tanaman terhadap cekaman rendaman. Pertambahan tinggi tanaman pada saat tanaman mengalami perendaman merupakan suatu kondisi yang tidak diinginkan karena akan menghabiskan simpanan karbohidrat yang nantinya dapat digunakan tanaman sebagai sumber energi pada masa pemulihan (Anandan \& Arunachalam, 2012; Tamang \& Fukao, 2015).
Oleh karena itu, tanaman yang mampu menahan pertambahan tingginya pada kondisi terendam dianggap lebih toleran dan memiliki peluang yang lebih besar untuk dapat bertahan hidup.

Pertambahan tinggi tanaman ini merupakan mekanisme alami tanaman untuk dapat keluar dari permukaan air. Mekanisme pemanjangan ruas batang tanaman dalam kondisi terendam ini lebih disebabkan oleh pengaruh etilen (Colmer et al., 2014; Huang et al., 2019). 


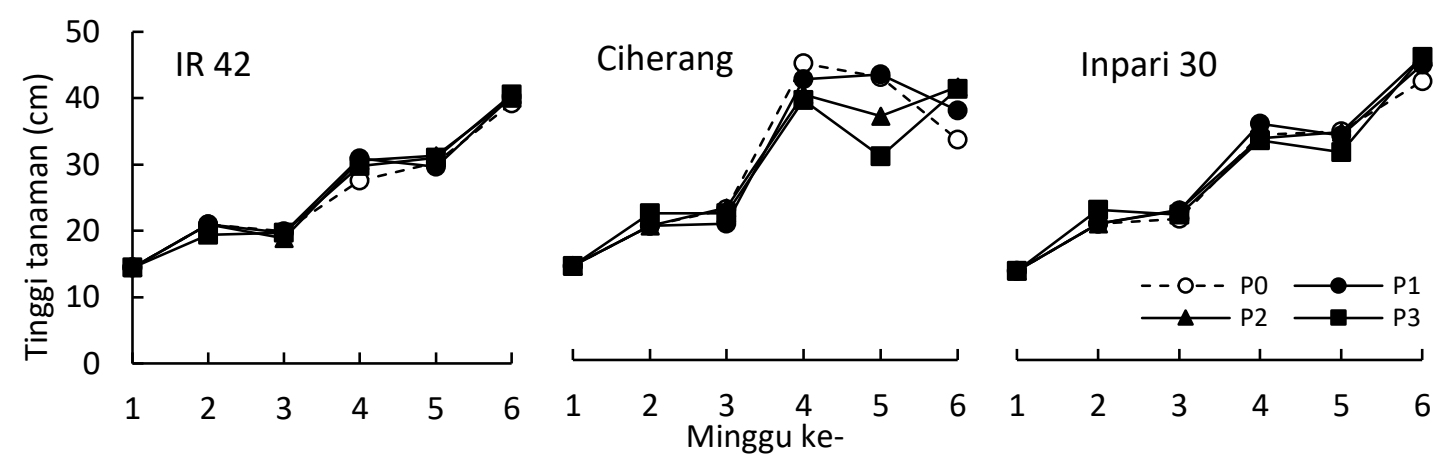

Gambar 1. Pertambahan tinggi tanaman padi selama 6 minggu setelah tanam

Sementara Inpari 30 memiliki pertambahan tinggi yang lebih rendah yang disebabkan adanya gen sub-1 sehingga tanaman mampu menekan pertumbuhan selama berada dalam kondisi terendam. IR
42 menunjukkan pertambahan tinggi yang paling sedikit dibandingkan dua varietas lainnya yang disebabkan kurang idealnya kondisi penelitian sehingga tinggi muka air pada bak IR 42 tidak maksimal.
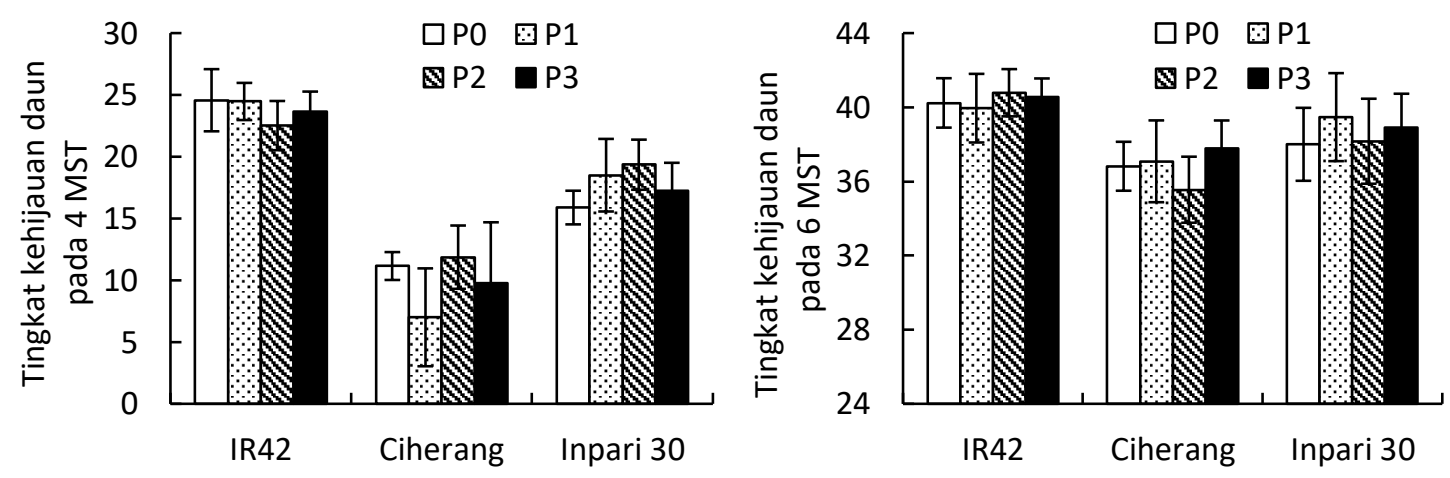

Gambar 2. Rerata nilai tingkat kehijauan daun pada kondisi cekaman rendaman, diukur pada 4 MST (setelah perendaman) dan 6 MST (14 hari masa pemulihan)

Pengukuran tingkat kehijauan daun dengan menggunakan SPAD meter dilakukan pada 4 MST atau tepat setelah tanaman selesai direndam, dan pada 6 MST atau setelah 14 hari masa pemulihan. Tingkat kehijauan daun dapat diasosiasikan dengan kandungan klorofil daun yang hasilnya dapat dilihat pada Gambar 2.

Hasil menunjukkan bahwa tingkat kehijauan daun yang diukur pada daun dengan umur yang sama (daun paling atas yang telah terbuka sempurna) selama masa perendaman umumnya jauh lebih rendah dibandingkan setelah masa pemulihan dengan varietas Ciherang yang memiliki tingkat kehijauan daun terendah.

Pada peubah luas daun dan total berat kering tanaman, hasil penelitian menunjukkan bahwa pemberian fosfor memberikan pengaruh yang signifikan. Pemberian fosfor berpengaruh sangat nyata terhadap peubah luas daun pada 6 MST, atau setelah 14 hari masa pemulihan. Berdasarkan hasil uji lanjut dengan BNT, (BNT1\% = 16,72) diperoleh bahwa perlakuan $\mathrm{P}_{2}$ memberikan hasil luas daun yang paling tinggi dengan $94,59 \mathrm{~cm}^{2}$ dan yang terendah pada $P_{0}$ (tanpa fosfor) dengan $71,24 \mathrm{~cm}^{2}$ (Gambar 3). 


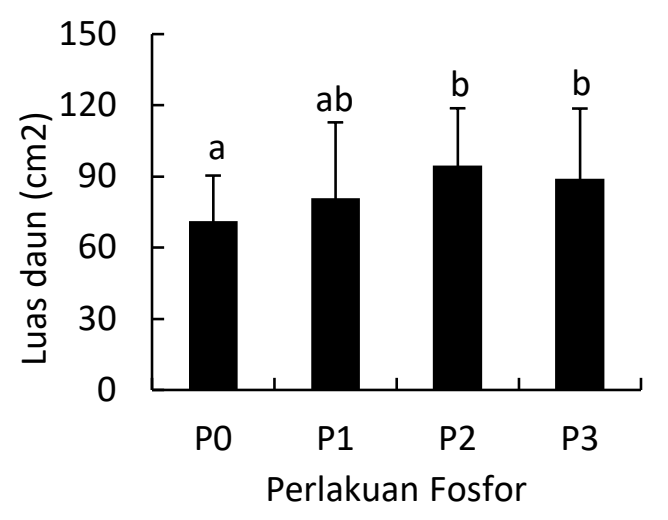

Gambar 3. Pengaruh pemberian fosfor terhadap rerata luas daun tanaman padi pada kondisi cekaman rendaman, diukur pada 6 MST (14 hari masa pemulihan)

Hasil uji lanjut dengan menggunakan BNT pada taraf $5 \%(B N T 5 \%=0,103)$ menunjukkan bahwa perlakuan $\mathrm{P}_{2}$ memiliki rerata total berat kering tanaman tertinggi dengan 0,69 $g$ yang tidak berbeda nyata dengan hasil pada perlakuan $\mathrm{P}_{1}$ dan $\mathrm{P}_{3}$ dengan masingmasing $0,60 \mathrm{~g}$ dan $0,67 \mathrm{~g}$. Sementara perlakuan kontrol $\left(\mathrm{P}_{0}\right)$ memiliki rerata berat kering total terendah dengan $0,53 \mathrm{~g}$ (Gambar 4).

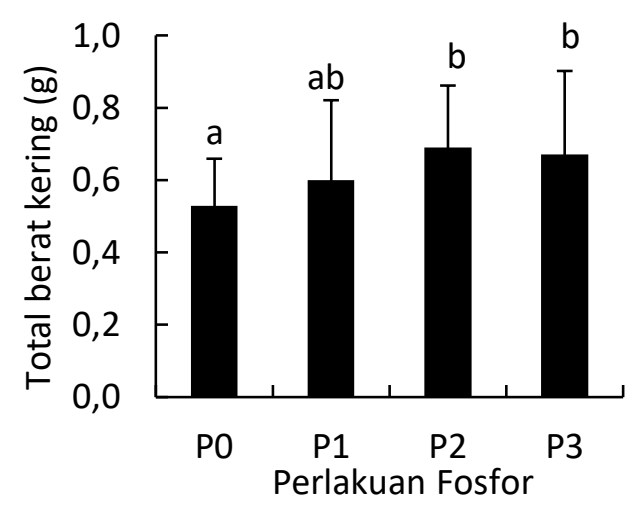

Gambar 4. Pengaruh pemberian fosfor terhadap rerata berat kering total tanaman padi pada kondisi cekaman rendaman, diukur pada 6 MST (14 hari masa pemulihan)
Semua karakter pertumbuhan mengalami penurunan selama fase perendaman. Terbatasnya oksigen dan cahaya yang diterima oleh daun menyebabkan terhambatnya proses metabolisme tanaman yang ditunjukkan dengan menurunnya tingkat kehijauan daun, luas daun dan berat kering tanaman. Dampak utama yang dialami tanaman dalam kondisi terendam adalah terhambatnya metabolisme tanaman yang berakibat menurunnya fotosintat dan produksi ATP sehingga energi yang dibutuhkan untuk pertumbuhan akar dan tajuk menjadi terbatas (Bailey-Serres et al., 2010).

Pada pengamatan 6 MST atau 14 hari masa pemulihan setelah perendaman, tanaman padi telah menunjukkan peningkatan pertumbuhan yang cukup signifikan. Hasil analisis sidik ragam yang dilakukan terhadap semua peubah pada 6 MST menghasilkan pengaruh nyata dari perlakuan fosfor untuk peubah luas daun dan total berat kering tanaman. Dua peubah ini merupakan peubah yang memiliki pengaruh besar terhadap pertumbuhan dan perkembangan tanaman. Luas daun mengindikasikan luas area intersepsi cahaya matahari yang dimanfaatkan dalam proses fotosintesis, sedangkan total berat kering tanaman mengindikasikan akumulasi karbohidrat hasil dari proses fotosintesis tanaman. Tanaman yang toleran terhadap cekaman rendaman umumnya akan mengalami penurunan cadangan karbohidrat yang lebih sedikit dibanding dengan tanaman yang sensitif (Singh et al., 2014). Lebih lanjut, Elanchezhian et al. (2013) melaporkan bahwa terdapat korelasi positif antara kandungan karbohidrat dan klorofil daun pasca terendam terhadap tingkat toleransi tanaman terhadap cekaman rendaman. Pada penelitian ini, 
perlakuan $\mathrm{P}_{2}$ menunjukkan pengaruh yang paling baik terhadap luas daun dan total berat kering tanaman dibandingkan dengan perlakuan fosfor lainnya.
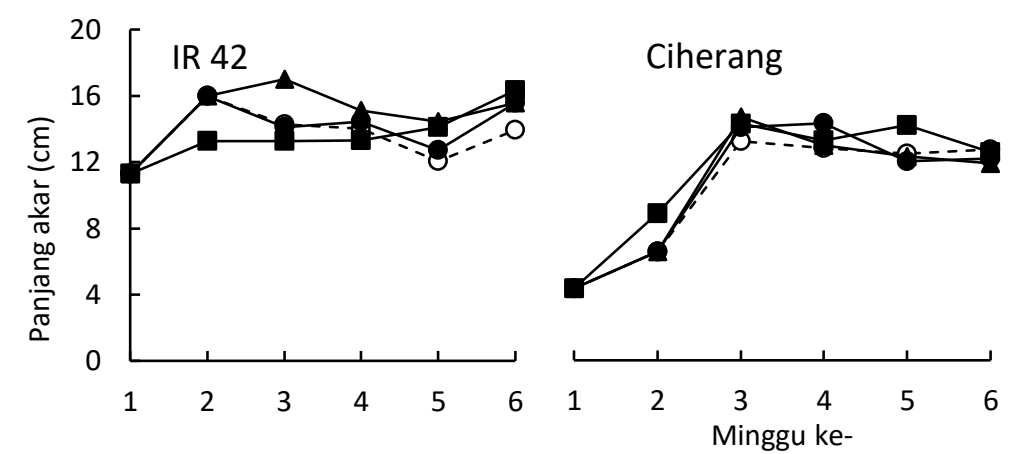

Inpari 30

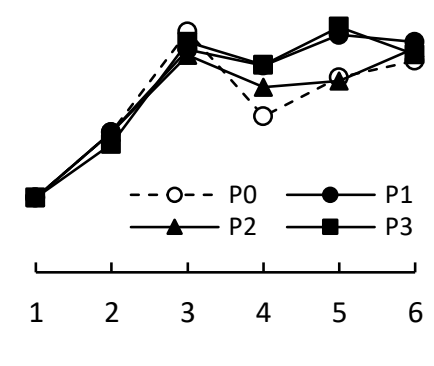

Gambar 5. Pertambahan rerata panjang akar tanaman padi selama 6 minggu setelah tanam rendaman

Terhambatnya pertumbuhan tanaman selama masa perendaman tidak hanya dialami oleh bagian tajuk tanaman, tetapi juga terjadi pada bagian akar. Pengamatan yang dilakukan pada 4 MST menunjukkan bahwa panjang akar mengalami penurunan dibandingkan dengan waktu sebelum terjadi perendaman. Tidak seperti bagian tajuk, pemulihan bagian akar tidak berlangsung cepat. Hal ini dapat dilihat pada Gambar 5 dimana panjang akar belum menunjukkan kecenderungan untuk meningkat bahkan setelah 14 hari masa pemulihan.

Untuk memperjelas pengaruh perlakuan fosfor terhadap bagian akar, analisis sidik ragam pun kemudian dilakukan untuk peubah berat kering akar yang menghasilkan pengaruh sangat nyata pada 6 MST (Fhit. = 7,45; F0,01 = 5,09) sehingga dilakukan pengujian lanjut menggunakan BNT pada taraf $1 \%$ untuk mengetahui pengaruh masing-masing perlakuan (Gambar 6). Dari hasil uji BNT (BNT1\% = 0,038 ) diperoleh bahwa perlakuan $P_{2}$ memberikan hasil terbaik sebesar $0,153 \mathrm{~g}$.

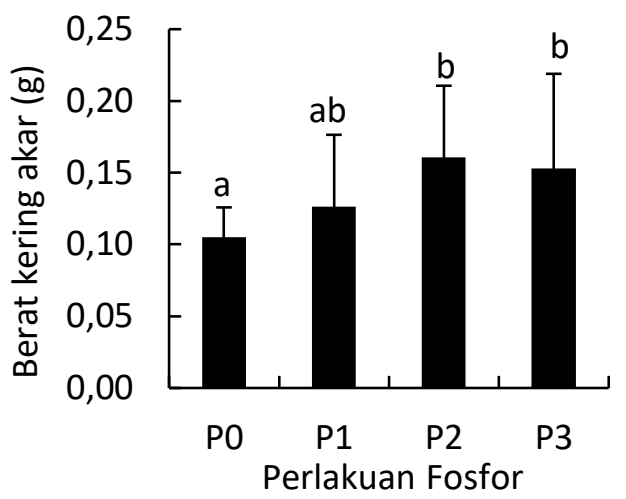

Gambar 6. Pengaruh pemberian fosfor terhadap rerata berat kering akar padi pada kondisi cekaman rendaman, diukur pada 6 MST (14 hari masa pemulihan)

Pada penelitian ini, beberapa tanaman sudah mulai memiliki anakan sejak 7 hari setelah masa pemulihan, dan pada 14 hari setelah masa pemulihan semua tanaman padi sudah memiliki anakan antara 2 sampai 6 anakan (Gambar 7). 


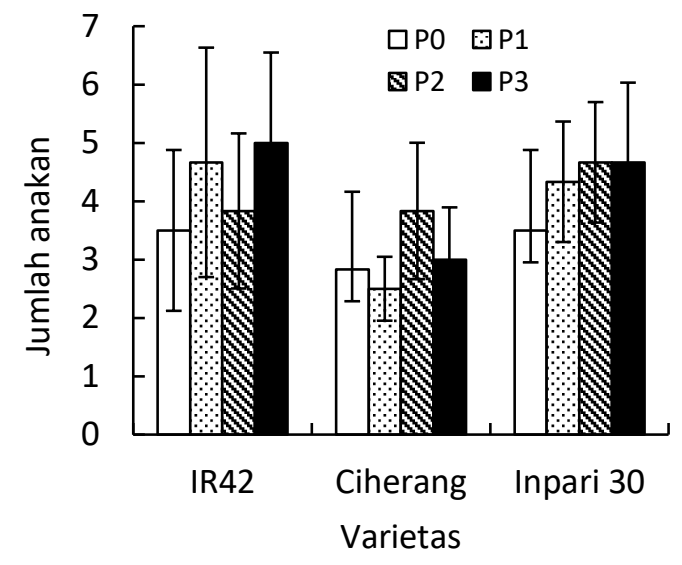

Gambar 7. Rerata jumlah anakan tanaman padi pada kondisi cekaman rendaman, diukur pada 6 MST (14 hari masa pemulihan)

Perlakuan fosfor tidak memberikan pengaruh yang signifikan terhadap peubah panjang malai. Berdasarkan hasil analisis sidik ragam, perbedaan yang terdapat pada peubah panjang malai lebih disebabkan oleh perbedaan varietas yang digunakan dalam penelitian ini. Varietas IR42 memiliki malai yang lebih pendek dibandingkan dengan kedua varietas lainnya, sementara Ciherang dan Inpari 30 memiliki malai dengan panjang yang relatif sama (Gambar 8).

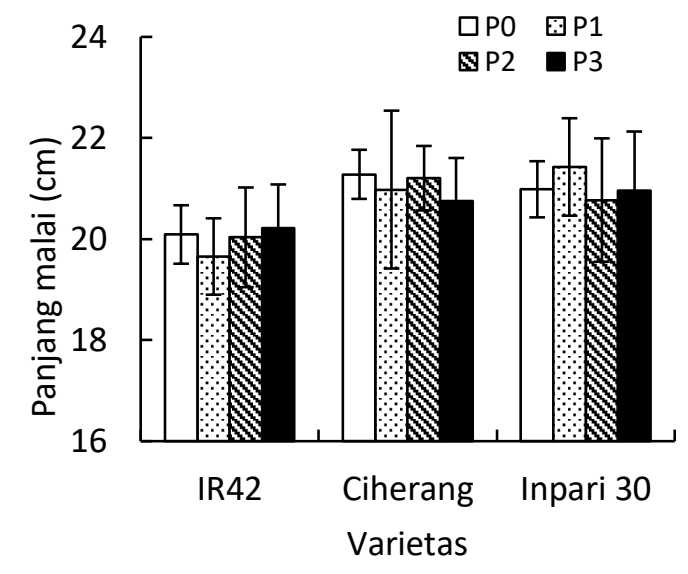

Gambar 8. Rerata panjang malai tanaman padi pada kondisi cekaman rendaman, diukur pada akhir penelitian
Hasil analisis sidik ragam juga menunjukkan bahwa perlakuan fosfor memberikan pengaruh yang tidak nyata terhadap peubah jumlah malai per rumpun. Perbedaan varietas lebih berpengaruh terhadap jumlah anakan per rumpun pada tiga varietas ini (Gambar 9). IR42 memiliki jumlah anakan yang lebih banyak dibandingkan Ciherang dan Inpari 30 dengan rerata sekitar 15-17 anakan per rumpun. Ciherang dan Inpari 30 memiliki rerata sekitar 11-14 anakan per rumpun.

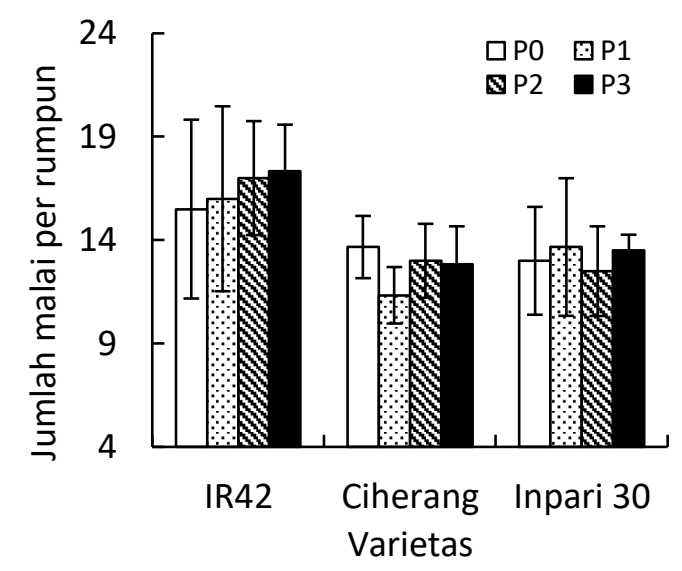

Gambar 9. Rerata jumlah malai per rumpun tanaman padi pada kondisi cekaman rendaman, diukur pada akhir penelitian

Peubah jumlah anakan, panjang malai dan jumlah malai per rumpun merupakan peubah yang dapat mengindikasikan produktivitas tanaman padi. Jumlah anakan akan sangat berkaitan dengan jumlah malai yang akan dihasilkan per rumpun, sedangkan panjang malai akan menentukan jumlah bulir per malai yang pada akhirnya akan menentukan jumlah bulir per rumpun. Berdasarkan hasil analisis sidik ragam, perlakuan fosfor memberikan pengaruh tidak nyata terhadap ketiga peubah ini. Perbedaan varietas merupakan faktor dominan penyebab terjadinya variasi nilai pada ketiga peubah ini. 


\section{SIMPULAN}

Kesimpulan yang dapat ditarik dari penelitian ini antara lain sebagai berikut:

1. Perlakuan $P_{2}$ (aplikasi fosfor pada 7 hari sebelum perendaman) menunjukkan hasil terbaik dibandingkan perlakuan lain yang secara signifikan ditunjukkan pada peubah luas daun, berat kering akar dan total berat kering tanaman pada 6 minggu setelah tanam atau 14 hari setelah perendaman.

2. Varietas Ciherang merupakan varietas yang mengalami pengaruh paling besar akibat cekaman rendaman dibandingkan dengan IR 42 dan Inpari 30. Inpari 30 sebagai varietas toleran pada penelitian ini juga menunjukkan respon yang cukup baik terhadap cekaman rendaman.

\section{UCAPAN TERIMAKASIH}

Terima kasih ditujukan kepada Rektor Universitas Sriwijaya yang telah menyetujui pendanaan kegiatan penelitian ini melalui Anggaran DIPA Badan Layanan Umum Universitas Sriwijaya tahun anggaran 2019 dengan nomor SP DIPA042.01.2.400953/2019 pada tanggal 05 Desember 2018 dan berdasarkan SK Rektor Penelitian Sains, Teknologi dan Seni nomor 0016/UN9/SK.LP2M.PT/2019 pada tanggal 21 Juni 2019.

\section{DAFTAR PUSTAKA}

Anandan, A., \& Arunachalam, P. (2012). Relative proportion of antioxidative enzyme activity in locally grown Indian rice cultivars (Oryza sativa L.) under submergence condition. Journal of Plant Interactions.

https://doi.org/10.1080/17429145.20

\subsection{7}

Bailey-Serres, J., Fukao, T., Ronald, P., Ismail, A., Heuer, S., \& Mackill, D. (2010). Submergence tolerant rice: SUB1's journey from landrace to modern cultivar Rice. https://doi.org/10.1007/s12284-0109048-5

Bhowmick, M. K., Dhara, M. C., Singh, S. Dar, M. H., \& Singh, U. S. (2014). Improved Management Options for Submergence-Tolerant (Sub1) Rice Genotype in Flood-Prone Rainfed Lowlands of West Bengal. American Journal of Plant Sciences. https://doi.org/10.4236/ajps.2014.51 003

BPS Sumsel. (2015). Luas lahan menurut penggunaan di Sumatera Selatan. Badan Pusat Statistik Sumatera Selatan.

Çalişkan, B., \& Çalişkan, A. C. (2018). Potassium Nutrition in Plants and Its Interactions with Other Nutrients in Hydroponic Culture. In Potassium Improvement of Quality in Fruits and Vegetables Through Hydroponic Nutrient Management. https://doi.org/10.5772/intechopen.7 1951

Colmer, T. D., Armstrong, W., Greenway, H., Ismail, A. M., Kirk, G. J. D., \& Atwell, B. J. (2014). Physiological Mechanisms of Flooding Tolerance in Rice: Transient Complete Submergence and Prolonged Standing Water. https://doi.org/10.1007/978-3-64238797-5_9

Elanchezhian, R., Kumar, S., Singh, S. S., Dwivedi, S. K., Shivani, S., \& Bhatt, B. P. (2013). Plant survival, growth and yield attributing traits of rice (Oryza sativa L.) genotypes under submergence stress in rainfed lowland 
ecosystem. Indian Journal of Plant Physiology.

https://doi.org/10.1007/s40502-0130050-y

Ella, Evangelina S. Ismail, A. M. (2006). Seedling nutrient states before submergence affects survival after submergence in rice. Crop Science. https://doi.org/10.2135/cropsci2005. 08-0280

Gautam, P., Nayak, A. K., Lal, B., Bhattacharyya, P., Tripathi, R., Shahid, M., Mohanty, S., Raja, R., \& Panda, B. B. (2014). Submergence tolerance in relation to application time of nitrogen and phosphorus in rice (Oryza sativa L.). Environmental and Experimental Botany. https://doi.org/10.1016/j.envexpbot. 2013.11.012

Gomez, K. A., Gomez, A. A., \& Gomez, K. A. (1984). Two-Factor Experiments. In Statistical procedures for agricultural research.

Huang, Y. C., Yeh, T. H., \& Yang, C. Y. (2019). Ethylene signaling involves in seeds germination upon submergence and antioxidant response elicited confers submergence tolerance to rice seedlings. Rice. https://doi.org/10.1186/s12284-0190284-z

Ismail, A. M., Johnson, D. E., Ella, E. S., Vergara, G. V., \& Baltazar, A. M. (2012). Adaptation to flooding during emergence and seedling growth in rice and weeds, and implications for crop establishment. AOB PLANTS. https://doi.org/10.1093/aobpla/pls01 9

Nishiuchi, S., Yamauchi, T., Takahashi, H., Kotula, L., \& Nakazono, M. (2012). Mechanisms for coping with submergence andwaterlogging in rice. In Rice. https://doi.org/10.1186/19398433-5-2

Setter, T. L., Bhekasut, P., \& Greenway, H. (2010). Desiccation of leaves after desubmergence is one cause for intolerance to complete submergence of the rice cultivar IR 42. Functional Plant Biology. https://doi.org/10.1071/FP10025

Singh, S., Mackill, D. J., \& Ismail, A. M. (2014). Physiological basis of tolerance to complete submergence in rice involves genetic factors in addition to the SUB1 gene. AoB PLANTS. https://doi.org/10.1093/aobpla/plu0 60

Tamang, B. G., \& Fukao, T. (2015). Plant adaptation to multiple stresses during submergence and following desubmergence. In International Journal of Molecular Sciences. https://doi.org/10.3390/ijms1612262 26

Waluyo, Suparwata, \& Supriyo, A. (2006). Teknologi usahatani padi di lahan lebak (Studi kasus: Desa Batu Ampar, Kab. OKI, Sumsel). Prosiding Seminar Nasional Inovasi Teknologi Dan Pengembangan Terpadu Lahan Rawa Lebak, 281-288. 